\title{
10 Disaster risk governance and gender professionals
}

\section{Command-and-control and re-doing gender}

\author{
By Bernadette P. Resurrección and Rebecca Elmhirst \\ In conversation with Maria Holtsberg, \\ Napapan Der Kinderen, and Hilde Jakobsen
}

\section{The inertia of emergency management in disaster risk reduction}

Disasters are now happening more frequently and more ferociously, summoning governments and various stripes of civil society organisations to escalate their actions to ensure more effective protection and safety of lives and property. In the last decades, the growing severity of disasters has beckoned the international disaster response community to more proactively reduce the risks of disasters by addressing their causes rather than limit action to emergency relief and management. In short, this represents a re-framing to pro-active disaster risk reduction (DRR) before a hazard can turn into a disaster (Baas, 2008). The disaster anthropologist, Anthony Oliver-Smith (2016), in tracing the evolution of DRR since the 1990s pointed out that DRR was an attempt to frame disaster in terms of risk that was generated by social, political and economic root causes, and among them, development. In 2005, for example, the General Assessment Report of the UNISDR* clearly cited the roots of contemporary disaster risk in historic and contemporary policies and practices of development. What followed was identifying first to third order DRR strategies, where the second and third order ones clearly aimed to neutralise the drivers of vulnerability, exposure and disaster risk.

Humanitarian studies scholar, Dorothea Hilhorst (2003), close to two decades ago, then already lamented that most disaster management organisations continue to pursue a hazard-centric approach akin to emergency management. This meant that they were still focused on delivering relief rather than proactively avoiding disasters by reducing risks, and framing hazards as external to society instead of locating and addressing its social, political and economic causes. Less than 20 years later, Oliver-Smith (2016: 75-76) expresses that nothing much has changed:

The major institutional focus is still on disaster management and emergency response. The core of the problem is a reluctance to confront the fact that disasters are not external and unforeseen shocks to an allegedly properly 
working economic and social system. Unfortunately, in the policy realm risk is still seen as an externality that requires management and preparation rather than as a socially constructed problem created by root or underlying causes that continue to be ignored despite their continuous manifestations in the workings of society. Most resources thus are still focused on emergency management and preparedness aimed toward reducing damage and compensating for losses rather than avoiding risk by addressing the underlying socially embedded causes and risk drivers that generate risk in the first place.

Hilhorst (2003) identified three domains of DRR, they are: (i) science and disaster management; (ii) disaster risk governance, and (iii) local responses. Within the domain of local responses we find a growing volume of grounded gender and disaster research (famously from the throes of hurricanes Andrew, Mitch, Katrina, and cyclones Haiyan and Nagar) that clearly demonstrates that the effects of disasters are profoundly gendered in multiple ways.

Gender and disasters research has developed in response to over five decades of research on emergencies, disasters and catastrophes where a 'calculated blindness' and conspicuous silence around gender persisted (Enarson, 2012: 2). Interest in gender emerged from earlier notions of social vulnerability in disaster contexts, where women and other marginalised groups were found to be disproportionately affected (Wisner et al., 2004; Bankoff et al., 2004). Research has also shown how in many places, women are specifically deprived of protection from natural hazards, which were more available to men and more powerful women in large part due to power relations and social life in highly stratified and conflictridden societies (Cupples, 2007; Hyndman, 2008; David \& Enarson, 2012). These studies also drew enormous attention to the need to focus on various aspects of gender and its intersections with ethnicity, class, race, age prior to, during and in the aftermath of disasters (Enarson, 1998; Enarson \& Morrow, 1998; Fordham, 2011; Fordham et al., 2011; Bradshaw, 2015). However, despite the explosion of research on gender and disasters, DRR practitioners remain frosty to genderresponsive action in their programming. For instance in Bangladesh, when first introducing the concept of gender, DRR staff gave it a decidedly cool reception, saying 'we are here to save lives; we do not have time for gender' (Eklund \& Tellier, 2012: 590). The resistance seems plausible, however, other accounts complicate and capture more dynamic interactions between professional staff in the domain of disaster risk governance as will be shown later in the chapter.

Disaster, humanitarian and DRR NGOs are varied, heterogeneous and with different histories. They have become quite complex because of efforts to closely link the longer-term goals of development with humanitarian work with uneven degrees of success and failures. In programmatic terms, organisations may include a diversity of programs that include peace-building, resilience-building, post-disaster reconstruction, disaster preparedness and disaster management. The same group of disaster-affected groups may be approached from a human rights, humanitarian or development perspective. Human rights work addresses legal aspects and protection of refugees; humanitarian efforts address shelter, medical 
services, food and water; while education and training are important for long-term development and resilience (Roth, 2015: 5).

In her book on humanitarian aid professionals, Silke Roth (2015) explores how women and men re-negotiate their gender positionings as they build their careers in humanitarian aid: by 'doing gender', they invoke and perpetuate gender differences, or by 'undoing gender', they challenge differences between men and women, masculinities and femininities. However, a more counter-intuitive outcome arises for example when women as mothers are made leaders of their organisations. Roth calls this a 're-doing' of gender, or in short, when the most unlikely means to achieve gender equality is through a factor that is believed to fundamentally perpetuate gender inequality.

Roth's study, however, focused on humanitarian aid professionals. Would these same 'doing gender' framings apply for gender experts in DRR organisations?

Despite growing research and attention to gendered disaster outcomes, very little research has pried open the social life of organisations where gender professionals have become part of DRR and disaster preparedness teams. This chapter is an attempt to address this gap through the experiential lens of three gender experts working in this field.

\section{Hilde and Napapan: 'command and control' in the humanitarian sector}

Practitioners in humanitarian aid and disaster risk reduction many times crisscross workspaces since there are opportunities today to link these two spheres, both normatively and in practical ways. DRR has been also framed to link more closely with the more long-term goals of sustainable development: 'the rationale for response has shifted from being a matter of public security and safety to one of public interest, investment and safety' (Bradshaw, 2015: 158). In turn, practising DRR is a longer-term process that helps build institutions to be better prepared for, resilient to and able to cope with hazards, and which usually focuses on predisaster stages (prevention, mitigation and preparedness), whereas humanitarian aid is usually short-term emergency relief and assistance to those who need help (Baas, 2008). Both Hilde Jakobsen and Napapan der Kinderen work in the DRR sphere but trace their careers to the humanitarian sector.

At the time of the conversation, Hilde was working for a DRR organisation as a senior gender advisor but seconded by a Swedish emergency agency for a specific program on gender and reducing disaster risk in Asia. Earlier, she worked in the humanitarian sector in Africa as a gender-based violence (GBV) adviser. She says she's new to the environment, disaster preparedness, and climate change side of gender work, which is linked more to development. In the program she is currently working in, she brings her experiences from working in refugee camps in Tanzania and focuses on post-disaster human trafficking and GBV.

Napapan der Kinderen works in the same DRR organisation as Hilde and has a background in law, human rights and public health. She says she has not taken up gender studies but has earlier worked on the protection of women and children, as 
well as GBV, in the humanitarian sector. Like Hilde, she claims she is also quite new in environment, development and disaster risk management. She has been recently hired to serve as the organisation's gender advisor, a position that was a recommendation by a major donor organisation that financially supports the organisation.

Hilde: Our organisation is, strictly speaking, not a humanitarian actor. Humanitarian action usually responds to complex emergencies. DRR work requires more engagement with local actors, supporting governments to be prepared themselves for responding to disasters especially when the international humanitarian community cannot come in. This organisation offers services to governments mainly for building their capacities for resilience-building, disaster risk management programming, and climate change adaptation.

Napapan: Yes, that's right. Our colleagues localise their actions, integrating their work to meet SDG goals and supporting governments, although recent trends in humanitarian work also try to increasingly link with development agendas.

Hilde and Napapan's experiences tell us that the gender issues they worked on while in the humanitarian sector take long for DRR organisations to fully accept and support. Especially since there have been recent efforts to 'localise' both DRR and humanitarian action wherein states can take primary action. Local women's organisations have been largely sidestepped, with far less recognition and support. Meaningful engagement with women and women's rights organisations could increase the success of the localisation agenda (Lafrenière et al., 2019)

Hilde: Napapan, you've been working on reproductive health issues during humanitarian crises. But now in our organisation, these issues do not play a central part and are not that well represented.

Napapan: Yes, I used to work on reproductive health issues in a refugee camp in Thailand. However, here in our organisation, they do not encourage discussion of it with our partners because they fear that that some governments do not welcome these issues. I feel that my competencies are not being fully put to use here.

For example, I was involved in a DRR training for a national disaster management organisation (NDMO) where mostly senior members were present. They rejected the data that I presented about the vulnerability of women being more than men's and questioned me on the source of the data and whether this came from official government records. I have also been told by my senior colleagues to be very cautious about discussing gender issues since many governments do not fully support or agree with these. They tell me stories of how in some trainings, debates became so heated regarding genderbased violence. Some participants simply do not accept that this is happening in their country. This has been a challenge.

Hilde: In humanitarian work, my experience was totally different. Tanzania has been known to have the first ever GBV program in the Burundi refugee 
camps. This, despite 'violence against women' being taboo in development circles then. So, I think in many ways, the humanitarian machinery can just go ahead and roll out a program, since as they used to say in the camps: 'We run these camps, we're doing this!' They didn't really care what other national colleagues or counterparts thought of the GBV program. And they could do this even without speaking Swahili, the national language. In this specific case, gender issues in humanitarian work have reached much further. And they've done this without really having to connect with the local community. They don't need acceptance on these issues from the national government as they've come in with their international humanitarian machinery. So, the caution that Napapan just described hasn't been so strong in humanitarian programs there since 'they're just going to run and do their own show.' In DRR, you are instead working with governments and so you need much more caution and buy-in, and I suppose the change you make is going to be more sustainable. As I said, despite the GBV program in the refugee camps, there was no GBV program in Tanzania in development circles even 15 years after the camp program as this has been widely thought to be sensitive and taboo. In development work, we have to squarely face and deal with the resistance.

Hilde's experience confirms discussions above about the conventional 'command and control' approach in the humanitarian sector. Ironically, it took this approach to advance the creation of gender programs and may be a process of 're-doing' gender (Roth, 2015), where the most unlikely groups use top-down, undemocratic means to achieve gender equality ends, or at least address the ills of GBV. However, this may have been a unique experience in large part due to the presence of international gender advisors like Hilde in the camps at the right time. Hilde however describes the sector as unapologetically male-dominated, referring to the Swedish emergency agency that seconded her to the DRR program:

Hilde: It's a very masculine domain. Those who are leaders or senior personnel were former fire fighters or are retired military personnel. It's not only a problem of the under-representation of women leaders in many humanitarian agencies, it's also a situation where there are so many incompetent men in leadership. They work for these agencies when their careers are not going well, and they're deployed to be in an NDMO for one or two years. They do not only play the gender card by resisting the presence of women, but they also resist other forms of knowledge other than mechanical engineering. The engineers are seen as the intellectuals among the plumbers and the mechanics. And the social sciences are not considered science.

In DRR as in humanitarian emergency management, strong associations with masculinity still remain, largely because its origins lie with the military and defence institutions of governments. Men still do control the leading emergency management agencies, do still dominate high-status professions and the upper echelons of emergency management organisations and do still benefit as a group from 
organisational cultures and reward systems tilting their way (Enarson, 2012: 177). Concurrently, many donors continue to conceptualise disaster as natural rather than social events. They continue to focus on their catastrophic outcomes rather than their social, political and economic causes, and as a result, they limit disaster work to catastrophe-related relief and reconstruction activities (Bradshaw, 2015).

Wilson (1999) adds that many of these centres were run by retired military personnel especially under the realm of the fire department, a traditionally maledominated sphere. For women entering the field of emergency management, women must modify their learned female characteristics to match men's work role characteristics. In the wake of disaster recovery efforts after Hurricane Katrina, Luft (2016: 16) later drew attention to the valorisation of physical labour and a militarised environment that spanned racial groups, which she refers to as racialised disaster patriarchy. Ericson and Mellström (2016: 11) introduce the idea of 'occupational heroism' that also promotes a culture of masculinity: 'Masculinity is institutionalized through networks of artefacts, representations and work practices that are interwoven with and expand certain male bodies.' The humanitarian sector also remains male-dominated at senior management levels (Hoare et al., 2012: 216).

Napapan experienced first-hand the challenges of raising gender awareness among the more conservative corners of governments where hegemonic disaster masculinities continue to thrive (Connell, 2005), and which her organisation was hesitant to unsettle. Both her and Hilde's work shows the uneasy path of gender advocacy that is activated within the continuum between humanitarian emergency management to DRR. Their experience also shows the tensions of combining humanitarian experience with development and DRR-orientated assignments. Experiences in these domains are diverse and sliding from one to the other requires sufficient grounding in the challenges that typically arise from each domain, especially when DRR continues to be framed by the inertia of humanitarian and emergency response programs.

Hilde became pregnant with her second child just before the first year of her secondment to the Asian DRR organisation ended. Her Swedish employers who seconded her to the DRR organisation in Asia did not continue her contract with them because of her pregnancy. She was then forced to leave the organisation because of her pregnancy. This is one more experience of 'command and control' in the disaster and emergency field as told by a gender expert.

Napapan has also already left the organisation as of this writing and has become a free-lance consultant. We now turn to the experience of Maria, showing how the internal social life in a DRR organisation 'does gender' in equally political ways.

\section{Maria: controlling gender in the DRR world}

Maria Holtsberg has a background in gender studies and worked for three-and-ahalf years as a gender specialist in a DRR organisation which she had just left at the time of this conversation. She has a master's in political science with a focus on women's empowerment and development studies. Earlier, she worked on 
issues of sexual and reproductive health in a UN agency and a European women's civil society organisation on sexual education. Gender programming, analysis and operationalising have always been components of her various assignments. She made use of her gender background in co-developing large-scale proposals and grant applications in the DRR organisation. However, she was never assigned to lead any program or project on gender, since 'gender' was only considered as something to be inserted in proposals with no standalone institutional presence. Being the only gender expert in her organisation, she began to strategise how to broaden the remit for gender-related activities.

Maria: I started forming a little group of UN and civil society gender experts outside of my organisation and initiating events. I was able to get the experts to do trainings and awareness raising events when my colleagues started hearing more about 'gender stuff' such as GBV from these experts, this gave gender work more credibility and usefulness. However, the lustre from these encounters did not rub off on our internal mundane operations like our recruitment practices, $\mathrm{M} \& \mathrm{E}$, and our own strategic planning.

In a massive re-structuring process and a new strategic framework that took two years to complete, it was decided that gender would be a core thematic area in Maria's organisation. She then contributed supporting papers to position gender more centrally in the new strategy. As it later turned out, it was decided that gender will no longer be a core thematic area but will instead have to be mainstreamed throughout the organisation. Thus, no leadership position was created specially to oversee gender-related projects and activities, and in the meantime, all new thematic areas - mostly technical in nature - were assigned their respective leaders. All designated leaders were men and were the former heads of earlier departments with new terms of reference that suited and aligned with their earlier scope of work and qualifications. Maria later met with the director of the organisation and he told her that she would lead and oversee the gender mainstreaming committee.

Maria: From my meeting with the director, it dawned on me that this was a junior position being offered to me, although it was one to be directly positioned under his office. My years in this organisation indicated to me that this modality meant that in the end, gender work will not be prioritised. It also dawned more fully on me that gender was not a priority in this organisation. It is also how things work here: the organisation is project-driven, and I did not come with any funding. There is no special position for a gender specialist unless it is donor funded. The proposed new position had no budget attached to it despite being created to serve as an advisory role to the director on genderrelated matters. In reality, I also think that traditional and cultural hierarchies and the way they work here will also not enable open consultations between myself and the director. It's just not common practice that seniors consult their junior counterparts in this culture. 
The paradoxical situation that Maria found herself in was a case where under the banner of gender mainstreaming, gender work was eventually nailed to the margins. Again, this twist was a case of 're-doing' gender along the terms defined by the organisation: gender ends up everywhere but really, nowhere.

Maria later led the development of a DRR proposal with a strong gender component. She was quite sure that she will not be asked to lead the project even if it resulted from her advocacy, which eventually turned out to be the case.

Maria: Even if the project materialised (which it has), I would not have been rewarded for my efforts, and it would not make a difference. I don't particularly care for the leadership role, but I am more concerned that gender was not given prominence in the overall re-structuring of the organisation and therefore it did not get a leadership position. I think someone with gender competency should be placed in the executive committee level for leverage, otherwise gender being a cross-cutting concern will continuously be side-lined.

What happened, Maria reflects, is also beyond gender, as she saw that employees in the organisation are generally protective of their own specific knowledge spaces and do not wish to expose their lack of knowledge or insecurities for new areas of work. These knowledge spaces constitute the domain of science and management within DRR that Hilhorst (2003) earlier alluded to. In this context, Maria believes that those who were experts in technical fields were assigned the leaders and their knowledge spaces remained virtually protected.

It is also possible that beyond gender lurk uneasy relations between local and international staff like Maria who provides or represents an 'outsider perspective' especially in traditionally 'taboo' areas like gender, which national staff may consider 'foreign' (Roth, 2012). She recalls that the understanding of gender and women's self-organising within the organisation was for lactating mothers to gather together for breastfeeding. This was a case of 'doing gender', marking differences between women and men, but doing so in culturally appropriate and acceptable ways, perpetuating traditional gender roles.

The organisation is also hierarchical where people in management have been long-time employees and young, junior members are given their assignments as a commonly accepted top-down practice. They also socialise and have strong partnerships with national disaster management organisations whose members do not advocate for gender equality as part of their normal order, and as Napapan's experience tells us, resistance is often overt. Some NGOs usually mirror state bureaucracies and adopt a state-centric design in their activities and programs, especially if their corporate identity, core operations and funding support are tied to their role as a service provider to states (Barnett, 2013; Srikandini et al., 2018).

Maria's story reveals that some disaster-related organisations may hire gender experts if it suits their cautionary terms of engagement: no leadership position for any gender expert which then weakens accountability for gender mainstreaming. The core expertise areas are technical services of early warning, forecasting, 
hazard cartography and GIS [geographic information system], which Barnett (2013) refers to as disaster technocracy. These technical areas were assigned leaders, and they were mostly men.

Finally, these types of expertise also define professional leadership in the organisation because they constitute a hazard-centred paradigm that relies on technologies to control disasters through measurement for prediction purposes (Hilhorst, 2003; Barnett, 2013). Gender would have landed on more fertile and welcoming ground had the orientation been true to the original tenets of disaster risk reduction that seek to address and reduce the gender inequality, social and political drivers of disaster risk in the first place.

The experiences and stories of Hilde, Napapan and Maria tie in closely with the gender and disaster literature about the persistent patriarchal practices in this domain. These patriarchal practices of command and control cut across the geographies of the global North and South, but also build on local intersectional gender, race and expertise politics that render DRR work still difficult terrain for those advocating gender equality.

\section{References}

Baas, S. (Ed.) (2008). Disaster Risk Management Systems Analysis: A Guide Book. Food and Agriculture Organization of the United Nations.

Bankoff, G., Hilhorst, D., \& Frerks, G. (2004). Mapping Vulnerability: Disasters, Development and People. Routledge.

Barnett, M. N. (2013). Humanitarian governance. Annual Review of Political Science, 16(1), 379-398. https://doi.org/10.1146/annurev-polisci-012512-083711

Bradshaw, S. (2015). Gender, Development and Disasters. Edward Elgar Publishing.

Connell, R. W. (2005). Hegemonic masculinity: Rethinking the Concept. Gender \& Society, 19(6), 829-859. https://doi.org/10.1177/0891243205278639

Cupples, J. (2007). Gender and Hurricane Mitch: Reconstructing subjectivities after disaster. Disasters, 31(2), 155-175. https://doi.org/10.1111/j.1467-7717.2007.01002.x

David, E., \& Enarson, E. P. (Eds.) (2012). The Women of Katrina: How Gender, Race, and Class Matter in an American Disaster. Vanderbilt University Press.

Eklund, L., \& Tellier, S. (2012). Gender and international crisis response: Do we have the data, and does it matter? Disasters, 36(4), 589-608. https://doi.org/10.1111/j.1467 $-7717.2012 .01276 . x$

Enarson, E. (1998). Through women's eyes: A gendered research agenda for disaster social science. Disasters, 22(2), 157-173. https://doi.org/10.1111/1467-7717.00083

Enarson, E., \& Morrow, B. H. (Eds.) (1998). The Gendered Terrain of Disaster: Through Women's Eyes. Praeger Publishers.

Enarson, E. P. (2012). Women Confronting Natural Disaster: From Vulnerability to Resilience. Lynne Rienner Publishers.

Ericson, M., \& Mellström, U. (2016). Firefighters, technology, masculinity in the micromanagement of disasters in operational service: Examples from Sweden. In E. P. Enarson \& B. Pease (Eds.), Men, Masculinities and Disaster (pp. 165-174). Routledge.

Fordham, M. (2011). Gender and disasters. In J. O. Nriagu (Ed.), Encyclopedia of Environmental Health (pp. 834-838). Elsevier. http://www.sciencedirect.com/science/ article/pii/B978044452272600475X 
Fordham, M., Gupta, S., Akerkar, S., \& Scharf, M. (2011). Leading Resilient Development: Grassroots Women's Priorities, Practices and Innovations. UNDP.

Hilhorst, D. (2003). Responding to disasters: Diversity of bureaucrats, technocrats and local people. International Journal of Mass Emergencies and Disasters, 21(1), 37-55.

Hoare, J., Smyth, I., \& Sweetman, C. (2012). Introduction: Post-disaster humanitarian work. Gender \& Development, 20(2), 205-217. https://doi.org/10.1080/13552074.20 12.698914

Hyndman, J. (2008). Feminism, conflict and disasters in post-tsunami Sri Lanka. Gender, Technology and Development, 12(1), 101-121. https://doi.org/10.1177/09718524070 1200107

Lafrenière, J., Sweetman, C., \& Thylin, T. (2019). Introduction: Gender, humanitarian action and crisis response. Gender \& Development, 27(2), 187-201. https://doi.org/10.1 080/13552074.2019.1634332

Luft, R. E. (2016). Racialized disaster patriarchy: An intersectional model for understanding disaster ten years after Hurricane Katrina. Feminist Formations, 28(2), 1-26. https:// doi.org/10.1353/ff.2016.0023

Oliver-Smith, A. (2016). Disaster risk reduction and applied anthropology: Disaster risk reduction. Annals of Anthropological Practice, 40(1), 73-85. https://doi.org/10.1111/ napa. 12089

Roth, S. (2012). Professionalisation trends and inequality: Experiences and practices in aid relationships. Third World Quarterly, 33(8), 1459-1474. https://doi.org/10.1080/0 9700161.2012.698129

Roth, S. (2015). The Paradoxes of Aid Work: Passionate Professionals. Routledge - Earthscan.

Sandler, J., \& Rao, A. (2012). The elephant in the room and the dragons at the gate: Strategising for gender equality in the 21 st century. Gender \& Development, 20(3), 547-562. https://doi.org/10.1080/13552074.2012.731741

Srikandini, A. G., Hilhorst, D., \& Voorst, R. V. (2018). Disaster risk governance in Indonesia and Myanmar: The practice of co-governance. Politics and Governance, 6(3), 180. https://doi.org/10.17645/pag.v6i3.1598

Wilson, J. (1999). Professionalization and gender in local emergency management. International Journal of Mass Emergencies and Disasters, 17(1), 111-122.

Wisner, B., Blaikie, P., Cannon, T., \& Davis, I. (2004). At Risk: Natural Hazards, People's Vulnerability and Disasters (Second Edition). Routledge. 